\title{
DIFFERENT ULTRAVIOLET SPECTROSCOPIC METHODS: A RETROSPECTIVE STUDY ON ITS APPLICATION FROM THE VIEWPOINT OF ANALYTICAL CHEMISTRY
}

\author{
PROMA MUKHERJEE ${ }^{1 *}$, DEBARUPA DUTTA CHAKRABORTY ${ }^{1}$, PRITHVIRAJ CHAKRABORTY ${ }^{2}$, \\ BHUPENDRA SHRESTHA ${ }^{1}$, NIHAR RANJAN BHUYAN ${ }^{1}$
}

${ }^{1}$ Department of Pharmaceutical Analysis, Himalayan Pharmacy Institute, Majhitar, Rangpo, East Sikkim, India. ${ }^{2}$ Department of Pharmaceutics, Himalayan Pharmacy Institute, Majhitar, Rangpo, East Sikkim, India. Email: proma96.mukherjee@gmail.com

Received: 25 May 2021, Revised and Accepted: 12 July 2021

ABSTRACT

In routine practice, some simple and rapid analytical methods are needed for the assessment of formulations containing multiple elements, complex matrix system and for biotherapeutic products. There are several methods available for ultraviolet (UV) spectrophotometry that rely on the concept of absorbance difference, absorbance spectra, and additivity, also included in the list are simultaneous equation method, Q-absorbance ratio method, derivative spectrophotometry, ratio derivative spectra, successive ratio-derivative spectra, absorption and absorptivity factor method, and difference spectrophotometry along with multivariate chemometric methods. In this review, emphasis has been given to the theories, mathematical context, advantages, and disadvantages along with the vast applications of UV spectrophotometry. The findings further highlighted that for the analysis of drugs, UV spectrophotometry remains as one of the most simple, cheap, and promising option for routine practice in the field of pharmaceuticals.

Keywords: Spectroscopy, Ultraviolet spectrophotometry, Absorptivity, Binary mixture.

(C) 2021 The Authors. Published by Innovare Academic Sciences Pvt Ltd. This is an open access article under the CC BY license (http://creativecommons.org/ licenses/by/4.0/) DOI: http://dx.doi.org/10.22159/ajpcr.2021v14i9.42172. Journal homepage: https://innovareacademics.in/journals/index.php/ajpcr

\section{INTRODUCTION}

Spectroscopy is the science which deals with the investigation of a spectra which is produced due to interaction of the molecules and is concerned with the interpretation of the absorbed and emitted electromagnetic radiation when the atoms or molecules changes its electronic state from one to another [1].

Ultraviolet (UV) spectroscopy is the study of absorption of the light which based on the Beer-Lambert law that states, the intensity of absorption is directly dependent on concentration and path length of species which get absorbed in the solution [2]. In analytical chemistry, this spectroscopy is widely used for the quantitative estimation of different analytes and biological molecules and also for the measurement of light intensity that passes through a chemical substance under investigation with respect to light intensity through a reference sample. The UV spectroscopy is also known as electronic spectroscopy as it results in the promotion of electrons from low energy to high energy state. This spectrophotometry is a simple, precise and a quite easy method to calculate the enumeration of aromatic conjugation and conjugated double bonds in different molecules. An analyst can utilize this technique for rapid analysis of multiple samples including liquids, solids, thin films, and glass [3].

\section{PRINCIPLE}

Any molecule or ion causes an electronic transition in its structure due to the radiation of light and therefore it will show absorption in the $\mathrm{UV}$ or visible region. In general, a molecule consists of either $\mathrm{n}$ (nonbonding), $\pi$ or $\sigma$ (bonding) electrons or its combination. By the supply of energy from light the electrons absorb radiation which promotes the transition of electrons from low to high energy state. The structure illustration of molecule can be done by the absorption peaks, and from the nature of electrons [1,3].

\section{VARIOUS UV SPECTROSCOPIC ANALYTICAL TECHNIQUES}

In analytical chemistry, diverse UV spectroscopic techniques are available which includes Simultaneous equation method, Q-absorbance ratio method, Derivative spectrometry, Difference spectrometry, Derivative ratio spectra, Successive ratio-derivative spectra, Absorption factor method, Absorptivity factor method, Absorbance subtraction method, Amplitude modulation method, Ratio subtraction method (RSM), Extended RSM (ERSM), Ratio difference spectrophotometric method, Constant center spectrophotometric method, and Multivariate chemometric method.

\section{SIMULTANEOUS EQUATION METHOD $[4,5]$}

Simultaneous equation method depends on the absorption of the two drugs in a binary or ternary mixture, each of them absorbs at the $\lambda_{\max }$ of other. These method follows some criteria which are:

- In a binary or ternary mixture which contain two different components (considered as $\mathrm{X}$ and $\mathrm{Y}$ ) each of them should absorb at the maximum wavelength of the other

- The maximum wavelength $\left(\lambda_{\text {max }}\right)$ of two different drugs should be different

- The two different drugs should not interact in the sample mixture.

The information required for the equation is

- Absorptivity of $\mathrm{X}$ at $\lambda_{1}$ and $\lambda_{2}$ is considered as $\mathrm{aX}$ and $\mathrm{aX}$

- Absorptivity of $\mathrm{Y}$ at $\lambda_{1}$ and $\lambda_{2}$ is considered as aY $\mathrm{Y}_{1}$ and $\mathrm{aY} \mathrm{Y}_{2}$

- Absorbance of diluted sample at $\lambda_{1}$ and $\lambda_{2}$ is considered as $A_{1}$ and $A_{2}$

- $\mathrm{Cx}$ and $\mathrm{Cy}$ is considered as the concentration of $\mathrm{X}$ and $\mathrm{Y}$, respectively, in the sample

- Total of absorbance of $\mathrm{X}$ and $\mathrm{Y}$ is equivalent with the absorbance of mixture

So,

At $\lambda_{1}, \mathrm{~A}_{1}=\mathrm{aX} \mathrm{b}_{1} \mathrm{Cx}+\mathrm{aY} \mathrm{b}_{1} \mathrm{Cy}$

At $\lambda_{2}, \mathrm{~A}_{2}=\mathrm{aX} \mathrm{b}_{2} \mathrm{Cx}+\mathrm{aY} \mathrm{Y}_{2} \mathrm{~b} \mathrm{Cy}$

If cell is $1 \mathrm{~cm}$, then $\mathrm{b}=1$

Multiply the equation (1) and (2) with $\mathrm{aX}_{2}$ and $\mathrm{aX}$

$\mathrm{A}_{1} \mathrm{aX}_{2}=\mathrm{aX}_{1} \mathrm{Cx}$ aX $2+\mathrm{aY}_{1} \mathrm{Cy} \mathrm{aX}_{2}$

$\mathrm{A}_{2} \mathrm{aX}_{1}=\mathrm{aX}_{2} \mathrm{Cx} \mathrm{aX}_{1}+\mathrm{aY}_{2} \mathrm{Cy} \mathrm{aX}_{1}$ 
Subtract the equation (4) from (3)

$$
\begin{aligned}
& \mathrm{A}_{1} \mathrm{aX}_{2}-\mathrm{A}_{2} \mathrm{aX}_{1}=a Y_{1} \mathrm{Cy} \mathrm{aX}_{2}-\mathrm{aY}_{2} \mathrm{Cy} a X_{1} \\
& \mathrm{~A}_{1} \mathrm{aX} \mathrm{X}_{2}-\mathrm{A}_{2} \mathrm{aX}=\mathrm{Cy}\left(\mathrm{aY}_{1} \mathrm{aX}_{2}-\mathrm{aY}_{2} \mathrm{aX}_{1}\right) \\
& \mathrm{Cy}=\left(\mathrm{A}_{1} \mathrm{aX}_{2}-\mathrm{A}_{2} \mathrm{aX}_{1}\right) /\left(\mathrm{aY}_{1} \mathrm{aX}_{2}-\mathrm{aY}_{2} \mathrm{aX}_{1}\right) \\
& \text { Similarly, }
\end{aligned}
$$

$\left.\left.\mathrm{Cx}=\left(\mathrm{A}_{2} \mathrm{aY}_{2}-\mathrm{A}_{1} \mathrm{aY}\right)_{1}\right) /\left(\mathrm{aY}_{1} \mathrm{aX} \mathrm{X}_{2}-\mathrm{aY}_{2} \mathrm{aX}\right)_{1}\right)$

From these simultaneous equation methods an analyst can determine drug concentration of $\mathrm{X}$ and $\mathrm{Y}$ in mixture.

\section{Advantage}

The method is beneficial because it allows determination of the concentration of each component in a multicomponent system which is present in the empirical and simulated data. It also gives a consistent result and a reliable calibration curve in case of a system which is not critically overlapping by choosing the relevant wavelengths [6].

\section{Disadvantage}

This method is applied only for the broad spectrum of which degree of overlap differs according to the relative concentration in case of multicomponent system. The region where the degree of overlapping is more, there only the one component get absorbed therefore the molar absorptivity tends to be less. It is also applicable for the combination of drugs which absorbs at the maximum wavelength of other [6].

\section{Q-ABSORBANCE RATIO METHOD}

Q-absorbance ratio method, a modified version of the simultaneous equation method, depends on the ratio of absorbance of a substance at two different wavelengths. One is the maximum wavelength of any one of two component and other is the wavelength of the iso-absorptive point $[4,5]$. This method is applicable for a combination of drugs which obeys Beer's law and the absorbance ratio at two wavelengths is a constant value which is independent of the path length and concentration. This constant is termed as Q-value or Hafner's Quotient $[7,8]$.

To determine drug concentration, the absorbance and absorptivity values at these wavelengths are calculated by the following equation

At $\lambda_{1} \mathrm{~A}_{1}=\mathrm{aX} \mathrm{Cx}_{1}+\mathrm{aY} \mathrm{Cy}_{1}$

At $\lambda_{2} \mathrm{~A}_{2}=\mathrm{aX}_{2} \mathrm{Cx}+\mathrm{aY}_{2} \mathrm{Cy}$

Divide the equation (8) with the equation (7)

$\mathrm{A}_{2} / \mathrm{A}_{1}=\left(\mathrm{aX}_{2} \mathrm{Cx}+\mathrm{aY} \mathrm{Y}_{2} \mathrm{Cy}\right) /\left(\mathrm{aX} \mathrm{Cx}_{1}+\mathrm{aY} \mathrm{C}_{1} \mathrm{Cy}\right)$

Divide both side with $(\mathrm{Cx}+\mathrm{Cy})$

$\mathrm{A}_{2} / \mathrm{A}_{1}=\left(\mathrm{aX}_{2} \mathrm{Cx}+\mathrm{aY} \mathrm{Y}_{2} \mathrm{Cy}\right) /(\mathrm{Cx}+\mathrm{Cy}) /\left(\mathrm{aX} \mathrm{Cx}_{1}+\mathrm{aY} \mathrm{C}_{1} \mathrm{Cy}\right) /(\mathrm{Cx}+\mathrm{Cy})$

Put $\mathrm{Fx}=\mathrm{Cx} /(\mathrm{Cx}+\mathrm{Cy})$ and $\mathrm{Fy}=\mathrm{Cy} /(\mathrm{Cx}+\mathrm{Cy})$

$\mathrm{A}_{2} / \mathrm{A}_{1}=\left[\mathrm{aX}_{2} \mathrm{Fx}+\mathrm{aY}_{2} \mathrm{Fy}\right] /\left[\mathrm{aX} \mathrm{Fx}_{1}+\mathrm{aY}_{1} \mathrm{Fy}\right]$

Where, Fx is the fraction of $\mathrm{X}$ and Fy is the fraction of Y that is Fy=1- Fx

Therefore,

$$
\begin{aligned}
& \mathrm{A}_{2} / \mathrm{A}_{1}=\left[\mathrm{aX}_{2} \mathrm{Fx}+\mathrm{aY} \mathrm{Y}_{2}(1-\mathrm{Fx})\right] /\left[\mathrm{aX} \mathrm{Fx}_{1}+\mathrm{aY}(1-\mathrm{Fx})\right] \\
& =\left[\mathrm{aX}_{2} \mathrm{Fx}+\mathrm{aY}_{2}-\mathrm{aY}_{2} \mathrm{Fx}\right] /\left[\mathrm{aX} \mathrm{Fx}_{1}+\mathrm{aY}_{1}-\mathrm{aY} \mathrm{Fx}_{1}\right]
\end{aligned}
$$

At iso-absorptive point
$\mathrm{aX}_{1}=\mathrm{aY}_{1}$ and $\mathrm{Cx}=\mathrm{Cy}$

Therefore,

$A_{2} / A_{1}=\left(a X_{2} F x+a Y_{2}-a Y_{2} F x\right) / a X$

$=\left(\mathrm{aX}_{2} \mathrm{Fx} / \mathrm{aX}_{1}\right)+\left(\mathrm{aY}_{2} / \mathrm{aX}_{1}\right)-\left(\mathrm{aY}_{2} \mathrm{Fx} / \mathrm{aX}_{1}\right)$

Let $\mathrm{Qx}=\mathrm{aX} / \mathrm{aX}, \mathrm{Qy}=\mathrm{aY} \mathrm{Y}_{2} / \mathrm{aY}_{1}$ and absorption ratio $\mathrm{Qm}=\mathrm{A}_{2} / \mathrm{A}_{1}$

$\mathrm{Qm}=\mathrm{FxQx}+\mathrm{Qy}-\mathrm{FxQy}$

$=F x(Q x-Q y)+Q y$

$F x=(Q m-Q y) /(Q x-Q y)$

From the equation (7)

$\mathrm{A}_{1}=\mathrm{aX}(\mathrm{Cx}+\mathrm{Cy})$

$\mathrm{Cx}+\mathrm{Cy}=\mathrm{A}_{1} / \mathrm{aX}$

$C x=\left(A_{1} / a_{1}\right)-C y$

From the equation (9)

$\mathrm{Cx} /(\mathrm{Cx}+\mathrm{Cy})=(\mathrm{Qm}-\mathrm{Qy}) /(\mathrm{Qx}-\mathrm{Qy})$

$\mathrm{Cx} /\left(\mathrm{A}_{1} / \mathrm{aX}_{1}\right)=(\mathrm{Qm}-\mathrm{Qy}) /(\mathrm{Qx}-\mathrm{Qy})$

$C x=[(Q m-Q y) /(Q x-Q y)]\left(A_{1} / a_{1}\right)$

\section{Advantage}

The advantage of this method is that the ratio of absorbance does not depend on the concentration and path length. It is a modified method of simultaneous equation method. It is a simple, reproducible, sensitive, and economical method $[7,8]$.

\section{Disadvantage}

It is only applicable for the combination of drugs which are having the isoabsorptive point and which follows Beer's law $[7,8]$.

\section{DIFFERENCE SPECTROMETRY}

Difference spectroscopy is a sensitive analytical technique which is used to demonstrate a chromophore ionization leading to identification and quantification of various components of a mixture [5]. This spectrophotometric technique is used to estimate the quantity of an analyte with the help of reference equimolar solution of that same analyte in different physicochemical conditions ( $\mathrm{pH}$ and temperature), based on their different spectral characteristics $[9,10]$.

Criteria for the assessment of a substance by difference spectrophotometry method are [5]:

- The analyte which is under investigation should exist in different chemical forms and exhibit different absorbance values. The absorbance difference is calculated from the amplitude difference in maxima and minima and plotted against concentration of test solution

- In case of distribution of spectrum of analyte any reproducible changes can occur by adding one or more reagent

- The reagents should not alter the absorbance of interfering substance.

Difference spectroscopy is used in simultaneous estimation of any multicomponent system as well as binary mixtures. Apart from any pharmaceutical assay, it is applied to the development of the biopharmaceutical formulation for the characterization of the protein structure and to determine the response of the protein structure to the formulation composition. The fact on which this application is based is 
that the high real time physical stability is given by the stable protein structure and it also provides difference spectra, used to quantify and characterize the changes in protein structure $[10,11]$.

\section{Advantage}

In case of the spectrophotometric analysis of the sample which contains interferents, in that case accuracy and selectivity can be distinctly improved using this approach of difference spectroscopy. Furthermore, by this method absorbance difference $(\Delta \mathrm{A})$ can be measured among the two equimolar solution of analyte which exhibit both different chemical forms and spectral characteristics [9-11].

\section{Disadvantage}

This method cannot be applicable when the reagents alter the absorbance of the interfering species and is only applicable for the analyte that exist in different chemical forms and exhibit different absorbance values [9-11].

\section{DERIVATIVE SPECTROPHOTOMETRY}

The concept of derivative spectroscopy deals with the transformation of a simple absorption spectrum to its derivative spectrum (first, second, or higher) based on wavelength. This spectroscopy is a method of manipulating the spectral data for the analytical situation in which the mixture exhibit interfering absorption and it is also used for spectral analysis to describe any chemical conformation [12].

In earlier days, there was a complexity because the derivative spectra were generated by wavelength modulation technique (optical method) and electrical method by using early UV visible spectrophotometers. But at the present time, an advanced software such as UV probe is introduced for generating derivative spectra directly from spectrophotometers, thus making this method largely practicable by reducing the need of additional mathematical process making it quicker and easier. In 1974, a new mathematical technique named as Golay-savitzky method was introduced and it became commercially popular [12-14].

Zero-order spectra are easier than derivative spectra. A first-order derivative spectrum is a graphical representation of the rate of change of absorbance against wavelength. A first-order derivative passes through zero point as $\lambda_{\text {max }}$ of the absorbance band and starts and finishes at the zero point. At the same wavelength, one side of this point shows positive band and other side shows negative band with both maxima and minima values, hence that point is called inflection point. In zero-order spectrum, the maximum positive and maximum negative slope correspond with a maximum and minimum slope of the first-order spectrum. In zero-order spectrum, the wavelength of zero slope is the $\lambda_{\text {max }}$ thus, in first order spectrum the value of $\mathrm{dA} / \mathrm{d} \lambda$ becomes zero [12].

The second-order derivative spectrum is a graphical representation of the zero-order spectrum against wavelength or a plot of $d^{2} A / d \lambda^{2}$ versus $\lambda$. At the same wavelength, the minimum negative band in the second order derivative spectrum is the maximum negative band in the zero-order spectrum, and the maximum positive bands in the zero-order spectrum also gives two small additional positive maxima which is called satellite band on both side of the main band in the second-order derivative spectrum [12]

If a spectrum is assumed as absorbance A, as a function of wavelength $\lambda$, the derivative spectra are[12]:

Zero-order

$A=f(\lambda)$

First-order

$\mathrm{D} 1=\mathrm{dA} / \mathrm{d} \lambda=\mathrm{f}^{\prime}(\lambda)$

Second-order

$\mathrm{D} 2=\mathrm{d}^{2} \mathrm{~A} / \mathrm{d} \lambda^{2}=\mathrm{f}^{\prime \prime}(\lambda)$
If we consider that zero-order spectrum comply with Beer's law so the circumference for all orders of derivative undergoes an identical direct relationship with concentration.

Consider,

Wavelength $=\lambda$

Absorbance $=\mathrm{A}$

Extinction coefficient $=\varepsilon$

Sample path length $=\mathrm{b}$

Sample concentration $=c$

Zero-order

$\mathrm{A}=\mathrm{\varepsilon bc}$

First-order

$\frac{d A}{d}=\frac{d}{d} b c$

$\mathrm{n}^{\text {th }}$ order

$d^{n} A / d \lambda^{n}=\left(d^{n} \varepsilon / d \lambda^{n}\right) b c$

\section{Advantage}

This method is advantageous since without any chemical pretreatment the samples of complex origin can be analyzed by direct UV analysis method. It also helps to contemplate the overlapping peaks of a multicomponent system; allows analysis at low sample content impurity profiling and by removing scattering and baseline shift, the spectral quality can be enhanced $[13,15,16]$.

\section{Disadvantage}

When the higher order derivatives are applied then the signal-to-noise ratio decreases and in case of modification of UV-visible spectrum for the first or higher derivative it results in a more complicated profile compared to zero-order spectrum. These are the unwanted effect of derivative spectroscopy [12]

\section{CONVOLUTED DERIVATIVE TECHNIQUE USING FOURIER FUNCTION [17-20]}

The core of harmonic analysis is that a given function, for example, D1 or D2 curves of a chromatographic peak or spectrophotometric curve, $f(\tau)$ can be expanded in terms of the Fourier series.

If $(n+1)$ is an even number then:

$f(\tau)=a_{0}+a_{1} \cos x+a_{2} \cos 2 x+\ldots+a_{(n+1) / 2} \cos ((n+1) / 2) x+b_{1} \sin x+b_{2} \sin$ $2 \mathrm{x}+\ldots+\mathrm{b}_{(\mathrm{n}-1) / 2} \sin ((\mathrm{n}-1) / 2) \mathrm{x}$

The calculation of the coefficients $a_{1}, a_{2}, a_{3} \ldots a_{1}$ and $b_{1}, b_{2}, b_{3} \ldots b_{j}$ is simplified since the trigonometric functions are mutually orthogonal.

Any coefficient $t$, can be calculated from a set of response data measured at equally spaced time intervals, by the following summation, in which $\mathrm{x}$ takes values from 0 to $2 \pi-[2 \pi /(n+1)]$, at intervals of $2 \pi /(n+1)$ :

$\mathrm{t}_{\mathrm{j}}=\Sigma \mathrm{f}(\tau)_{\mathrm{i}} \mathrm{Tx}_{\mathrm{i}} / \Sigma\left(\mathrm{Tx}_{\mathrm{i}}\right)^{2}$

Where T represents cosine or sine.

The Fourier function coefficients, $\left(t_{j}\right)$ are proportional to $f(\tau)$.i.e.:

$t_{j}=\alpha_{j} c$ 
Where $\alpha$ is a constant and $\mathrm{c}$ is the concentration of the analyte.

\section{Advantage [17]}

This method is advantageous because it eliminates all types of interferences and helps to produce high degree of purity in case of analytical peaks.

\section{Disadvantage [17]}

The disadvantage of this method is that it does not correct linear interference. When the Fourier transform is carried out, band limitation of the signal might result.

\section{DERIVATIVE TECHNIQUE UNDER ORTHOGONAL POLYNOMIAL FUNCTION AT UNEQUAL INTERVALS $[21,22]$}

In the spectrophotometric analysis of multicomponent system orthogonal function method can be applied for correcting the unnecessary absorption.

In general, the core of harmonic analysis is that, a given function, for example, D1 of absorbance curve can be expanded in terms of an orthogonal function for unequal intervals.

Thus,

$\mathrm{D} 1=\mathrm{k}_{0} \mathrm{~K}_{0}+\mathrm{k}_{1} \mathrm{~K}_{1}+\mathrm{k}_{2} \mathrm{~K}_{2}+\mathrm{k}_{3} \mathrm{~K}_{3}+\mathrm{k}_{4} \mathrm{~K}_{4}+\mathrm{k}_{5} \mathrm{~K}_{5}+\ldots+\mathrm{k}_{\mathrm{n}} \mathrm{K}_{\mathrm{n}}$

Where D1 is the first derivative which is belongs from a set of $\mathrm{n}+1$ unequally spaced wavelengths. $\mathrm{K}_{0}, \mathrm{~K}_{1}, \mathrm{~K}_{2}, \mathrm{~K}_{3}, \mathrm{~K}_{4}, \mathrm{~K}_{5}, \ldots \mathrm{Kn}$ are the polynomials which are similar to constant, linear, quadratic, cubic, quartic, quantic, etc., and $\mathrm{k}_{0}, \mathrm{k}_{1}, \mathrm{k}_{2}, \mathrm{k}_{3}, \mathrm{k}_{4}, \mathrm{k}_{5}, \ldots, \mathrm{k}_{\mathrm{n}}$ are there related coefficients. From the view of orthogonality, the polynomials can be calculated according to the method of Grandage and George [22] based on the following

$$
\begin{aligned}
& \sum_{\mathrm{i}=0}^{\mathrm{n}} \mathrm{K}_{\mathrm{ij}}=0 \\
& \sum_{\mathrm{i}=0}^{\mathrm{n}} \mathrm{K}_{\mathrm{ij}} \mathrm{K}_{\mathrm{iu}}=0 \text {, Where } \mathrm{j} \neq \mathrm{u}
\end{aligned}
$$

Where $\mathrm{j}$, $\mathrm{u}$ represent different polynomial orders. Any coefficient, $\mathrm{k}_{\mathrm{ij}}$, can be calculated from a set of first derivative data by the equation

$\mathrm{k}_{\mathrm{ij}}=\sum_{\mathrm{i}=0}^{\mathrm{n}} \mathrm{D} 1 \mathrm{~K}_{\mathrm{ij}} / \sum_{\mathrm{i}=0}^{\mathrm{n}} \mathrm{K}_{\mathrm{ij}}^{2}$

The denominator of this equation is the sum of the squared individual values of $\mathrm{K}_{\mathrm{ij}}$.

After the construction of the convoluted polynomial curves of each analyte, the orthogonal polynomial coefficient, $\mathrm{k}_{\mathrm{ij}}$, at any $\lambda$ are proportional to D1 and concentration, thus

$\mathrm{k}_{\mathrm{ij}}=\alpha_{\mathrm{j}} \mathrm{C}_{\mathrm{a}}$

Where $\alpha=\mathrm{k}_{\mathrm{i}}(1 \%, 1 \mathrm{~cm})$ is a constant which correspond to absorptivity of the pure compound, $\mathrm{a}$, and $\mathrm{C}_{\mathrm{a}}$ is the concentration of the absorbing compound A.

\section{Advantage [21]}

This method is advantageous because it selectively and specifically determines the drugs when the matrix interferences are present. In case of multicomponent analysis, this method corrects the insignificant absorption.

\section{Disadvantage [21]}

This is a time-consuming method because it has many mathematical steps and requires a large amount of training sets.

\section{RATIO DERIVATIVE SPECTROSCOPY}

In earlier days ratio derivative spectroscopy has been appeared as an appropriate method to determine two or more compounds in the same sample without any initial separation. In case of binary mixtures of compounds with strongly overlapped spectra, managing with the level of interference was problematic with the derivative technique [23]. To fix this crisis, ratio derivative method has been established. By the concurrent use of zero crossing technique [24-26] and Salinas method, this method has been widened to determine ternary mixtures [27-29].

\section{The information required for this equation is [30]} Let us consider,

A is mixture of two compounds, $\mathrm{A}$ and $\mathrm{B}$

The absorbance of sample mixture at $\lambda_{1}$ is $\mathrm{A}_{\mathrm{M}}{ }^{\lambda}{ }_{1}$

Molar absorptivity of compound $\mathrm{A}$ and $\mathrm{B}$ is $\mathrm{E}_{\mathrm{A}, 1}^{\lambda}$ and $\mathrm{E}_{\mathrm{B}, 1}{ }_{1}^{\lambda}$

Concentration of $\mathrm{A}$ and $\mathrm{B}$ is $\mathrm{C}_{\mathrm{A}}$ and $\mathrm{C}_{\mathrm{B}}$

The absorbance spectrum of the sample mixture is given by the following equation:

$\mathrm{A}_{\mathrm{M}, 1}^{\lambda}=\mathrm{E}_{\mathrm{A}, 1}^{\lambda} \mathrm{C}_{\mathrm{A}}+\mathrm{E}_{\mathrm{B}, 1}^{\lambda} \mathrm{C}_{\mathrm{B}}$

Above equation is divided by absorbance of standard solution of $\mathrm{A}$ at $\lambda_{1}$, whose concentration is $\mathrm{C}_{\mathrm{A}}^{0}$ that is $\mathrm{E}_{\mathrm{A} 1}{ }_{1} \mathrm{C}_{\mathrm{A}}^{0}$ then the equation becomes:

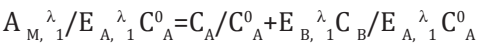

This equation can be simplified to:

$\mathrm{A}_{\mathrm{M}, 1}^{\lambda} / \mathrm{E}_{\mathrm{A}, 1}^{\lambda}=\mathrm{C}_{\mathrm{A}}+\left(\mathrm{E}_{\mathrm{B}, 1}^{\lambda} / \mathrm{E}_{\mathrm{A}, 1}^{\lambda}\right) \mathrm{C}_{\mathrm{B}}$

Differentiating equation (16) with respect to $\lambda$, gives

$\mathrm{d} / \mathrm{d} \lambda\left(\mathrm{A}_{\mathrm{M}, 1}{ }_{1} / \mathrm{E}_{\mathrm{A}}{ }^{\lambda}\right)=\mathrm{C}_{\mathrm{B}} \mathrm{d} / \mathrm{d} \lambda\left(\mathrm{E}_{\mathrm{B}, 1}{ }_{1} / \mathrm{E}_{\mathrm{A}, 1}{ }_{1}\right)$

This equation indicates that the derivative ratio spectrum of sample mixture is dependent only on the values of $\mathrm{C}_{\mathrm{B}}$ and it is independent of the value of $\mathrm{C}_{\mathrm{A}}$.

\section{Advantage $[23,30]$}

It allows the use of highest wavelength value of the analytical signals which have different maxima and minima. Thus, it gives a scope for finding out the active compounds when the excipients and other compounds which cause interference are present in the assay. It is an appropriate method to determine two or more compounds in the same sample without any initial separation. This method cancels out the derivative step and the use of zero-crossing points and sophisticated chemometric method is not required.

\section{Disadvantage $[23,30]$}

The main disadvantage of this method is that it has many manipulating steps such as division and calculation of the derivative and another disadvantage of this technique is that it is very much dependent on the instrumental parameters such as slit width and scanning speed.

\section{SUCCESSIVE RATIO DERIVATIVE SPECTRA METHOD}

This method is established for the simultaneous estimation of pharmaceutical drug component in ternary mixture without knowing the ratio of the concentration of drugs in mixture and apart from any initial separation [31].

Let's consider the three compounds as X, Y, and Z. If Beer's law is obeyed in whole wavelength range used and considering the path length as $1 \mathrm{~cm}$, absorbance of ternary mixture at each wavelength can be written as: 
$\mathrm{A}_{\mathrm{m}}=\alpha_{\mathrm{X}} \mathrm{C}_{\mathrm{X}}+\alpha_{\mathrm{Y}} \mathrm{C}_{\mathrm{Y}}+\alpha_{\mathrm{Z}} \mathrm{C}_{\mathrm{Z}}$

Where,

$\mathrm{A}_{\mathrm{m}}$ is absorbance of sample mixture.

$\alpha_{\mathrm{X}}, \alpha_{\mathrm{Y}}$ and $\alpha_{\mathrm{Z}}$ are the absorptivity values of $\mathrm{X}, \mathrm{Y}$ and $\mathrm{Z}$.

$\mathrm{C}_{\mathrm{X}}, \mathrm{C}_{\mathrm{Y}} \mathrm{C}_{\mathrm{Z}}$ are concentrations of $\mathrm{X}, \mathrm{Y}$ and $\mathrm{Z}$ respectively.

Dividing the equation (18) by $\alpha_{z}$, corresponding to the spectrum of a standard solution of $\mathrm{Z}$ in ternary mixture, the first ratio spectrum is achieved in the form of equation (19) (the zero values of $\alpha_{z}$ should not be used in the divisor for the possibility of dividing operation)

$\mathrm{B}=\mathrm{A}_{\mathrm{m}} / \alpha_{\mathrm{Z}}=\left(\alpha_{\mathrm{X}} \mathrm{C}_{\mathrm{X}} / \alpha_{\mathrm{Z})}+\left(\alpha_{\mathrm{Y}} \mathrm{C}_{\mathrm{Y}} / \alpha_{\mathrm{Z})}+\alpha_{\mathrm{Z}}+\mathrm{C}_{\mathrm{Z}}\right.\right.$

When the first derivative of equation (19) is taken then $C_{z}$ (derivative constant) is zero, and then equation (20) would be obtained

$\mathrm{dB} / \mathrm{d} \lambda=\mathrm{d} / \mathrm{d} \lambda\left(\alpha_{\mathrm{X}} \mathrm{C}_{\mathrm{X}} / \alpha_{\mathrm{Z})}+\mathrm{d} / \mathrm{d} \lambda\left(\alpha_{\mathrm{Y}} \mathrm{C}_{\mathrm{Y}} / \alpha_{\mathrm{Z}}\right)\right.$

The equation (20) is divided by $(\mathrm{d} / \mathrm{d} \lambda)\left(\alpha_{\mathrm{y}} / \alpha_{\mathrm{z}}\right)$, corresponding to derivative of ratio of the spectra of standard solutions of $Y$ and $Z$, the second ratio spectrum is obtained as equation (21) (the zero values of $(d / d \lambda)\left(\alpha_{Y} / \alpha_{Z}\right)$ should not be used in the divisor for the possibility of dividing operation):

$\mathrm{D}=(\mathrm{dB} / \mathrm{d} \lambda) /\left[(\mathrm{d} / \mathrm{d} \lambda)\left(\alpha_{\mathrm{\gamma}} / \alpha_{\mathrm{Z}}\right)\right]=\left[(\mathrm{d} / \mathrm{d} \lambda)\left(\alpha_{\mathrm{x}} \mathrm{C}_{\mathrm{x} /} \alpha_{\mathrm{Z}}\right)\right] /\left[(\mathrm{d} / \mathrm{d} \lambda)\left(\alpha_{\mathrm{\gamma}} / \alpha_{\mathrm{z}}\right)\right]+\mathrm{C}_{\mathrm{Y}}$

When the first derivative of equation (21) is taken then $C_{Y}$ (derivative constant) is zero, and then equation (22) would be obtained.

$\mathrm{dD} / \mathrm{d} \lambda=\mathrm{d} / \mathrm{d} \lambda\left[\left\{\mathrm{d} / \mathrm{d} \lambda\left(\alpha_{\mathrm{X}} \mathrm{C}_{\mathrm{X}} / \alpha_{\mathrm{Z}}\right)\right\} /\left\{\mathrm{d} / \mathrm{d} \lambda\left(\alpha_{\mathrm{Y}} \mathrm{C}_{\mathrm{Y}} / \alpha_{\mathrm{Z}}\right)\right\}\right]$

Equation (22) is the mathematical structure of multicomponent analysis which allows estimation of concentration of every active compound in the solution (X) without any interference from other compounds of ternary mixture (Y and Z). The equation (22) builds a direct relationship among the concentration of $X$ in the solution and amount of $d / d \lambda$.

A calibration curve is plotted by taking $\mathrm{dD} / \mathrm{d} \lambda \mathrm{v} / \mathrm{s}$ concentration of $\mathrm{X}$ in ternary mixture (standard). The amount of $\mathrm{dD} / \mathrm{d} \lambda$ correlates with wavelength having maximum or minimum values should be estimated to achieve more sensitivity. Calibration curves for $\mathrm{Y}$ and $\mathrm{Z}$ also could be plotted as stated for X.

\section{Advantage [31]}

This method is established for the simultaneous estimation of pharmaceutical drug component in ternary mixture without knowing the ratio of the concentration of drugs in mixture and also there is no need of any initial separation. Only the two successive steps of the successive derivative of the ratio spectra are required for this method.

\section{Disadvantage [31]}

It can be applied only for the mixture of two interfering substances whose ratio of the concentration is known, and it should be same for the unknown sample.

\section{ABSORPTIVITY FACTOR METHOD}

This is the modified UV spectroscopy method of absorption method. For performing this method there are following criteria: [32]

- In particular, for binary mixture this method is utilized

- There must be maximum difference in between the absorptivity values of both drugs

- Iso-absorptive point should not be present.

In case of iso-absorptive point method, crossing of spectra may occur at different concentrations of drugs. For the absorptivity method, in that crossing point absorptivity is equivalent with the ratio of concentrations which is inversed is used. Hence, the ratio is called as absorptivity factor (F) and the crossing point is called as absorptivity factor point [32-35].

$A_{X}=a_{X} b c_{X}$ and $A_{Y}=a_{Y} b c_{Y}$

At crossing point of equal absorptivity having different drug concentrations

$$
\begin{aligned}
& A_{X}=A_{Y} \\
& a_{X} b c_{X}=a_{Y} b c_{Y} \\
& a_{X} c_{X}=a_{Y} c_{Y} \\
& a_{X} / a_{Y}=c_{X} / c_{Y}=F \\
& a_{X} / a_{Y}=F \\
& A_{m}=A_{X}+A_{Y}=a_{X} b c_{X}+a_{Y} b c_{Y}
\end{aligned}
$$

Where,

$\mathrm{b}=1$

$\mathrm{A}_{\mathrm{m}}=\mathrm{a}_{\mathrm{X}} \mathrm{c}_{\mathrm{X}}+\mathrm{a}_{\mathrm{Y}} \mathrm{c}_{\mathrm{Y}}$

$\mathrm{a}_{\mathrm{X}}=\mathrm{F} \mathrm{a}_{\mathrm{Y}}$

$A_{m}=F a_{Y} c_{X}+a_{Y} c_{Y}$

$=\mathrm{a}_{\mathrm{Y}}\left(\mathrm{F} \mathrm{c}_{\mathrm{X}}+\mathrm{c}_{\mathrm{Y}}\right)$

The concentration of drug Y can be determined using linear regression equation between its concentration and absorbance at the wavelength where the maximum absorption has taken place and also there is no interference of other drugs. Concentration of drug $\mathrm{X}$ also can be determined from the concentration of $\mathrm{Y}$ using the following equation:

$$
\begin{aligned}
& \mathrm{A}_{\mathrm{m}}=\mathrm{a}_{\mathrm{Y}}\left(\mathrm{F} \mathrm{c}_{\mathrm{X}}+\mathrm{c}_{\mathrm{Y}}=\mathrm{a}_{\mathrm{X}}\left(\mathrm{F} \mathrm{c}_{\mathrm{Y}}+\mathrm{c}_{\mathrm{X}}\right)\right. \\
& \mathrm{c}_{\mathrm{X}}=\left[\left(\mathrm{F} \mathrm{c}_{\mathrm{X}}+\mathrm{c}_{\mathrm{Y}}\right)-\mathrm{c}_{\mathrm{Y}}\right] / \mathrm{F}
\end{aligned}
$$

\section{Advantage [32]}

It is the modified method of classical absorption method and it is a novel technique. For calculating the concentration of two drugs in binary mixture an easy mathematical equation is used.

\section{Disadvantage [32]}

This method is only applicable for the binary mixture of drugs which does not have any isoabsorptive point and it is applicable only for the drugs which having larger difference in absorptivity.

\section{ABSORPTION FACTOR METHOD}

Absorption factor method, a spectroscopic method, also used for the analysis of binary sample mixtures having overlapping spectra and, in those cases, where it is found that one compound exhibits some interference at the $\lambda_{\max }$ of another compound, while another compound does not exhibit any interference at the $\lambda_{\max }$ of the other compound [36].

Let's consider a mixture of $\mathrm{X}, \mathrm{Y}$ having a wavelength maxima at $\lambda_{\mathrm{X}}$ and $\lambda_{Y \text { where }}$ Y shows some interference at $\lambda_{X}$ but $X$ does not show interference at $\lambda_{\mathrm{Y}}$. Then, from the binary mixture of $\mathrm{X}, \mathrm{Y}$ by subtracting the value of absorption $\mathrm{Y}$ at $\lambda_{\mathrm{X}}$, the absorption value of $\mathrm{X}$ can be calculated quantitatively. The absorption factor which is calculated experimentally is applied for the calculation $[37,38]$. The equation is as follows:

Absorption value of $\mathrm{X}$ at $\lambda_{\mathrm{X}}=\mathrm{Abs} \lambda_{\mathrm{x}}(\mathrm{X}+\mathrm{Y})-\mathrm{Abs} 1 / \mathrm{Abs} 2 * \mathrm{Abs}_{\mathrm{y}}(\mathrm{X}+\mathrm{Y})$

Where,

Abs1 and Abs2 is the absorbance of $\mathrm{Y}$ at $\lambda_{\mathrm{X}}$ and $\lambda_{\mathrm{Y}}$ 
Abs1/Abs2=absorption factor (it is a constant value for pure compound Y)

$\operatorname{Abs} \lambda_{\mathrm{x}}(\mathrm{X}+\mathrm{Y})$ and $\mathrm{Abs} \lambda_{\mathrm{y}}(\mathrm{X}+\mathrm{Y})$ are the absorption of the mixture at two wavelengths that is $\lambda_{\mathrm{X}}$ and $\lambda_{\mathrm{Y}}$.

\section{Advantage [36]}

This method is applicable for the ex vivo and in vitro characterization of the drugs for topical delivery. It is also applicable for the drugs which are present in the biological samples. This method is used for the estimation of the concentration of drugs in formulation which is based on nanostructured lipid carriers.

\section{Disadvantage [36]}

It is only used for the analysis of the drugs which has overlapping spectra in the binary sample mixture and also only applicable in those cases, where it is found that one compound exhibits some interference at the $\lambda_{\text {max }}$ of another compound, while another compound does not exhibit any interference at the $\lambda_{\text {max }}$ of the other compound.

\section{ABSORBANCE SUBTRACTION METHOD [39]}

The principle of this method is similar to the principle of absorption factor method and the method is applied for the analysis of the binary mixture of drugs ( $\mathrm{X}$ and $\mathrm{Y}$ ) having overlapped spectra which intersect the isoabsorptive point and also it is found that one compound exhibits some interference at the $\lambda_{\max }$ of another compound, while another compound does not exhibit any interference at the $\lambda_{\max }$ of the other compound.

The absorbance values of component $\mathrm{X}$ and $\mathrm{Y}$ at $\lambda_{\text {iso }}$ are calculated by the help of absorbance factor $\left\{A_{\text {iso }} / A_{2}\right\}$ is a constant for the pure component $\mathrm{Y}$ which represents the average of the ratio between the absorbance values of different concentrations of pure component $Y$ at $\lambda_{\text {iso }}\left(A_{\text {iso }}\right)$ at $\lambda_{2}\left(\mathrm{~A}_{2}\right)$

Absorbance of $\mathrm{Y}$ in the mixture at $\lambda_{\text {iso }}=\left(\right.$ abs1/abs2) $\times$ abs $\lambda_{2}(\mathrm{X}+\mathrm{Y})$

Absorbance of $\mathrm{X}$ in the mixture at $\lambda_{\text {iso }}=\mathrm{abs} \lambda_{\text {iso }}(\mathrm{X}+\mathrm{Y})-(\mathrm{abs} 1 / \mathrm{abs} 2) \times \mathrm{abs}$ $\lambda_{2}(\mathrm{X}+\mathrm{Y})$

Where abs 1 and abs 2 are the absorbance of pure compound $Y$ at $\lambda$ iso and $\lambda_{2}$; abs1/abs2 is absorbance factor and abs $\lambda_{\text {iso }}(\mathrm{X}+\mathrm{Y})$ and abs $\lambda_{2}(\mathrm{X}+\mathrm{Y})$ are the absorbance of the mixture at these wavelengths $\left(\lambda_{\text {iso }} \lambda_{2}\right)$.

The concentration of the drugs (X and Y) can be determined by this method.

\section{Advantage [39]}

This is a novel, simple accurate, specific spectrophotometric method which is applied for the simultaneous determination of two drugs and also there is no need of prior separation steps. Any complementary steps of spectrophotometric method does not require for the estimation of concentration of one component from the mixture of two components.

\section{Disadvantage [39]}

In case of a component which has low concentration and the low absorbance value at the extended region the risk of error gets increased when the absorbance factor is calculated by this method.

\section{AMPLITUDE MODULATION METHOD [39]}

This method is novel spectrophotometric method of ratio spectra manipulation by the help of normalized spectra. It is applied for the analysis of binary mixture ( $\mathrm{X}$ and $\mathrm{Y}$ ) where the component $\mathrm{Y}$ is extended over the component $\mathrm{X}$ and the spectra of both drugs shows an isoabsorptive point at the zero spectrum.

The absorbance of the zero-order absorption spectrum of binary mixture at isoabsorptive point is as follows:

$$
\left[\mathrm{A}_{\mathrm{m}}\right]=\left[\mathrm{a}_{\mathrm{X}} \mathrm{C}_{\mathrm{X}}\right]+\left[\mathrm{a}_{\mathrm{Y}} \mathrm{C}_{\mathrm{Y}}\right]
$$

Dividing eq (25) with normalized spectrum of $\mathrm{Y}$ as a divisor

$$
\begin{aligned}
& {\left[\mathrm{A}_{\mathrm{m}}\right] /\left[\mathrm{a}_{\mathrm{Y}} \mathrm{C}_{\mathrm{Y}}\right]=\left[\mathrm{a}_{\mathrm{X}} \mathrm{C}_{\mathrm{X}}\right] /\left[\mathrm{a}_{\mathrm{Y}} \mathrm{C}_{\mathrm{Y}}\right]+\left[\mathrm{a}_{\mathrm{Y}} \mathrm{C}_{\mathrm{Y}}\right] /\left[\mathrm{a}_{\mathrm{Y}} \mathrm{C}_{\mathrm{Y}}\right]} \\
& {\left[\mathrm{A}_{\mathrm{m}}\right] /\left[\mathrm{a}_{\mathrm{Y}} \mathrm{C}_{\mathrm{Y}}\right]=\left[\mathrm{a}_{\mathrm{X}} \mathrm{C}_{\mathrm{X}}\right] /\left[\mathrm{a}_{\mathrm{Y}} \mathrm{C}_{\mathrm{Y}}\right]+\text { constant }} \\
& \mathrm{P}_{\mathrm{m}}=\mathrm{P}_{\mathrm{X}}+\mathrm{P}_{\mathrm{Y}}
\end{aligned}
$$

Where, $\mathrm{P}_{\mathrm{m}}$ is the amplitude of ratio spectrum of binary mixture

$\mathrm{P}_{\mathrm{X}}$ is the amplitude of component $\mathrm{X}$

$\mathrm{P}_{\mathrm{Y}}$ is the amplitude of component $\mathrm{Y}$.

The recorded amplitude of ratio spectrum at isosbestic point is equal to the sum of amplitude which is corresponding to component $\mathrm{X}$ and that corresponding to component Y.

$\mathrm{P}_{\mathrm{Y}}$ is constant and can be directly determined by the spectrum where the straight line is parallel with the axis of wavelength in the area where the spectrum of $Y$ is extended.

Since, we can use the normal divisor of $\mathrm{Y}$ so, $\mathrm{C}_{\mathrm{Y}^{\prime}}=1 \mu \mathrm{g} / \mathrm{mL}$

$\mathrm{P}_{\mathrm{Y}}=\left[\mathrm{a}_{\mathrm{Y}} \mathrm{C}_{\mathrm{Y}}\right] /\left[\mathrm{a}_{\mathrm{Y}} \mathrm{C}_{\mathrm{Y}}\right]$

$\mathrm{P}_{\mathrm{Y}}=\left[\mathrm{C}_{\mathrm{Y}}\right]$

For the estimation of amplitude of component X, we have to subtract the value of constant from the ratio spectrum of mixture at isosbestic point

$\mathrm{P}_{\mathrm{X}}=\mathrm{P}_{\mathrm{m}}-\mathrm{P}_{\mathrm{Y}}$

$\mathrm{P}_{\mathrm{X}}=\left\{\left[\mathrm{a}_{\mathrm{X}} \mathrm{C}_{\mathrm{X}}\right] /\left[\mathrm{a}_{\mathrm{Y}} \mathrm{C}_{\mathrm{Y}}\right]+\right.$ constant $\}-$ constant

$\mathrm{P}_{\mathrm{X}}=\left[\mathrm{a}_{\mathrm{X}} \mathrm{C}_{\mathrm{X}}\right] /\left[\mathrm{a}_{\mathrm{Y}} \mathrm{C}_{\mathrm{Y}^{\prime}}\right]$

At the isosbestic point $\mathrm{a}_{\mathrm{X}}=\mathrm{a}_{\mathrm{Y}}$

And the normalized divisor of $\mathrm{Y}_{\mathrm{Y}^{\prime}}=1 \mu \mathrm{g} / \mathrm{mL}$

$\mathrm{P}_{\mathrm{X}}=\left[\mathrm{a}_{\mathrm{X}} \mathrm{C}_{\mathrm{X}}\right] /\left[\mathrm{a}_{\mathrm{Y}} \mathrm{C}_{\mathrm{Y}^{\prime}}\right]$

$\mathrm{P}_{\mathrm{X}}=\mathrm{C}_{\mathrm{X}}$

The concentration X and Y can be calculated by the help of the following regression equation.

$\mathrm{C}_{\text {recorded }}=$ Slope $\mathrm{C}+$ intercept

Slope is found approximately one and intercept is almost zero.

\section{Advantage [39]}

It is a novel spectrophotometric method which is simple to implement and also it is an economic method. For estimation of the components in binary mixture only one divisor is required and by the help of the constant other mathematical manipulation steps can be reduced. By the help of the divisor the amplitude of ratio spectrum represents the concentration of the component directly. As there is no need for the calculation step of absorbance factor in the lower absorbance sample, thus there is no chance for risk of error

\section{Disadvantage [39]}

In case of a drug mixture, if there is no existence of isoabsorptive point at the ratio spectra and zero point of both components of the mixture this method cannot be applicable. If the spectrum of one component is not extended, then this method cannot be applicable. 


\section{RSM [37]}

In case of a binary mixture ( $\mathrm{x}$ and $\mathrm{y}$ ) having an overlapped spectra, the spectra of component $y$ are more extended than component $\mathrm{x}$, then the component $x$ can be determined by dividing the spectra of binary mixture by a specific concentration of component y as a divisor $\left(\mathrm{y}^{0}\right)$.

Due to this a new curve is obtained which represents $\left(\mathrm{x} / \mathrm{y}^{0}\right)+$ constant. If the constant is subtracted and the new curve which is obtained after subtraction is multiplied by $\mathrm{y}^{0}$ then zero order $\mathrm{D}^{0}$ spectrum of $\mathrm{x}$ can be estimated. This can be represented by following equations

Step 1: $(\mathrm{x}+\mathrm{y}) / \mathrm{y}^{0}=\left(\mathrm{x} / \mathrm{y}^{0}\right)+\left(\mathrm{y} / \mathrm{y}^{0}\right)=\left(\mathrm{x} / \mathrm{y}^{0}\right)+$ constant

Step 2: $\left(\mathrm{x} / \mathrm{y}^{0}\right)+$ constant - constan $\mathrm{t}=\mathrm{x} / \mathrm{y}^{0}$

Step 3: $\left(\mathrm{x} / \mathrm{y}^{0}\right) \times \mathrm{y}^{0}=\mathrm{x}$

This constant can be directly estimated from curve $(x+y) / y^{0}$ by the spectrum where the straight line is parallel with the axis of wavelength in the area where the spectrum of $\mathrm{y}$ is extended.

\section{Advantage [37]}

It is a novel spectrophotometric method applied for the simultaneous determination of multicomponent pharmaceutical formulation without having any prior separation and there is no need of derivatization.

\section{Disadvantage [37]}

The limitation for the RSM is that it is applied only for the determination of non-extended component; therefore, this method cannot be applied for the determination of extended component.

\section{ERSM [37]}

For the determination of $y$, which is a second component, the extension has been done for the previously developed method which is established as a newer proposal called as ERSM.

In this method component y can be estimated by dividing the previously obtained $\mathrm{D}^{0}$ spectra of component $\mathrm{x}$ by the help of concentration of component $\mathrm{x}$ which is known to calculate the value of constant $\left(\mathrm{x} / \mathrm{x}^{0}\right)$. The spectra of mixture $(x+y)$ are divided by same divisor $\left(x^{0}\right)$. From this division, a new curve is obtained that represents $\left(x / x^{0}\right)+\left(y / y^{0}\right)$, where $\mathrm{x} / \mathrm{x}^{0}$ is constant which is previously obtained. If the constant is subtracted, and the new curve which is obtained after subtraction is multiplied by $\mathrm{x}^{0}$ then zero order $\mathrm{D}^{0}$ spectrum of $\mathrm{y}$ can be estimated.

$(x+y) / x^{0}=\left(x / x^{0}\right)+\left(y / x^{0}\right)-\left(x / x^{0}\right)=\left(y / x^{0}\right) \times x^{0}=y$

Concentration of y can be calculated by the help of the regression equation which represents the linear relationship among the absorbance at its maximum wavelength against the related concentration of y [40].

\section{Advantage [37]}

This method can be applied for the determination of both (extended and non-extended) components and there is no need of any prior separation step. Furthermore, there is no need of any derivative step and it does not require any special program, special technique and any sophisticated apparatus. This method showed maximum accuracy, precision, and reproducibility.

\section{Disadvantage [37]}

In case of estimation of the concentration of drug when it is coupled with other methods then it requires extra processing. And also it requires more time for performing this method on each mixture.

\section{RATIO DIFFERENCE SPECTROPHOTOMETRIC METHOD (RD) AND} CONSTANT CENTRE SPECTROPHOTOMETRIC METHOD [41]

It is a suitable method for the simultaneous estimation of two drugs which having the overlapped spectra. This method is based on the theory which states that there should be two requirements first one is that the interfering substance should give some contribution at each one of wavelengths and the second one is that ratio values of the selected wavelengths should not be similar.

Constant center method contains two complementary steps of each other such as constant calculation along with amplitude difference method subsequent with constant multiplication.

First step for constant calculation along with amplitude difference method based on that, in case of a binary mixture which contains two drugs ( $\mathrm{X}$ and $\mathrm{Y}$ ) having overlapping spectra, then we can estimate $\mathrm{X}$ by dividing binary mixture spectrum by the concentration of $X$ which is previously known. Then a new curve will be obtained that represents.

$\mathrm{X}+\mathrm{Y} / \mathrm{X}^{\prime}$ i.e. $\mathrm{X} / \mathrm{X}^{\prime}+\mathrm{Y} / \mathrm{X}^{\prime}$

Where $\mathrm{X} / \mathrm{X}$ ' is constant. This can be summarized as follows:

$(\mathrm{X}+\mathrm{Y}) / \mathrm{X}^{\prime}=\mathrm{Y} / \mathrm{X}^{\prime}+\mathrm{X} / \mathrm{X}^{\prime}=\mathrm{Y} / \mathrm{X}^{\prime}+\mathrm{constant}$

From the obtained ratio curve, two wavelengths $\left(\lambda_{1}\right.$ and $\left.\lambda_{2}\right)$ are selected and at $\left(\mathrm{Y} / \mathrm{X}^{\prime}\right) 1$ and $\left(\mathrm{Y} / \mathrm{X}^{\prime}\right) 2$ points the values of ratio are subtracted then the constant $\left(\mathrm{X} / \mathrm{X}^{\prime}\right)$ accompanied with any instrumental error or any other interference from interfering substance $\mathrm{X}$ will cancel out. These differences will represent only the component $\mathrm{Y}$ and then.

$\mathrm{P} 1$ - P2=(Y/X')1+constant $-\left\{\left(\mathrm{Y} / \mathrm{X}^{\prime}\right) 2+\right.$ constant $\}$

$\mathrm{P} 1-\mathrm{P} 2=\left(\mathrm{Y} / \mathrm{X}^{\prime}\right) 1-\left(\mathrm{Y} / \mathrm{X}^{\prime}\right) 2$

Where at $\lambda 1$ and $\lambda 2$ the ratio amplitude of ratio spectrum are P1 and P2.

Amplitude difference method starts with computation of regression equation representing the linear relationship between $\mathrm{n}$ the ratio amplitudes difference of concentration of component $Y$ at $\lambda 1$ and $\lambda 2$ using a specific concentration of $\mathrm{X}^{\prime}$ as a divisor against the related ratio amplitude at the one wavelength of any two.

Therefore $\left\{\left(Y / X^{\prime}\right) 1-\left(Y / X^{\prime}\right) 2\right\}=$ slope $\left(Y / X^{\prime}\right) 1+$ intercept

Where, $\left\{\left(Y / X^{\prime}\right) 1-\left(Y / X^{\prime}\right) 2\right\}$ is the difference of ratio spectra

Amplitude at $\lambda 1$ and $\lambda 2$ and $\left(\mathrm{Y} / \mathrm{X}^{\prime}\right) 1$ is the corresponding ratio amplitude at $\lambda 1$.

The postulated amplitude value is ( $\left.\mathrm{Y} / \mathrm{X}^{\prime}\right) 1$ ( $\mathrm{P}$ postulated) which is related with component $\mathrm{Y}$ can be determined using computed regression equation which is previously reported by using ratio difference amplitude at two different wavelength.

The constant valueX/X' can be calculated along with amplitude difference method by subtracting the recorded amplitude of ratio spectrum of the mixture $Y / X^{\prime}+X / X^{\prime}$ (P recorded) at $(\lambda 1)$, and its postulated amplitude at the same wavelength $\{\Delta \mathrm{P}$ recorded - postulated $\}$

Then

$X / X^{\prime}=\left\{Y / X^{\prime}+X / X^{\prime}\right\} 1-\left\{Y / X^{\prime}\right\} 1$

i.e., $\mathrm{C} . \mathrm{V}=[\mathrm{P}$ recorded $]-[\mathrm{P}$ postulated $]$

Where, C.V is the constant value $\mathrm{X} / \mathrm{X}$, $\mathrm{P}$ recorded is recorded peal amplitude of the mixture at $(\lambda 1)$ and $P$ postulated is the postulated peak amplitude at $(\lambda 1)$.

The absorption spectrum of $\mathrm{X}$ at zero-order can be obtained along with another step which is called constant multiplication step where we have to multiply the constant value with the divisor $\mathrm{X}^{\prime}$. 
$\mathrm{X}=\left(\mathrm{X} / \mathrm{X}^{\prime}\right) \times \mathrm{X}^{\prime}$

Concentration of component $\mathrm{X}$ can be determined by the help of corresponding regression equation which represents the linear relationship among the absorbance values of zero order spectrum of $\mathrm{X}$ at its maximum wavelength against the corresponding concentration of component X. Correspondingly, concentration of component Y in binary mixture can be estimated by the help of same two steps.

\section{Advantage [41]}

The method is very accurate, simple, and precise and for this method any complicated computer programs and sophisticated apparatus is not required. As this method permits the constant value calculation; thus, it is regarded as a modified approach of ratio difference method. This method is more advantageous than the second derivative method in case of measuring the concentration of drug in zero-order because it is more accurate.

\section{Disadvantage [41]}

It is applicable for the binary mixture of drugs and the method is not applicable when the divisor should not comprise with the maximum sensitivity and minimum noise.

\section{MULTIVARIATE CHEMOMETRIC METHOD}

Multivariate chemometric method can be done by the multiple measurements of the same sample for the correlation of the physical properties of the sample with analytical data. It is mainly a mathematical technique of processing analytical data, where it is easy to estimate nonselective signals, then amalgamating them in a multivariate model $[7,42]$.

Multivariate methods include:

1. MLR or Multiple linear regression methods

i. K-matrix or Classical least squares

ii. P-matrix or Inverse least squares.

2. Factor based methods

i. $\quad$ Principle component regression (PCR)

ii. Partial least squares (PLS).

In case of MLR and PCR techniques data is organized as matrices of the column vectors, while for PLS technique data are organized as the matrices of the row vectors $[7,42]$.

Chemometric contrivance can be done for improving the results of absorbance in dissolution profiling study, which is resulting from a lower concentration of previous points in dissolution timing by the help of derivative method (first and second) corresponding to the Fourier function convoluted method. Chemometric methods can be applied in biowaiver study for correcting the interferences, for this reason chemometric aided spectrophotometry can be contemplated as an innovation in biowaiver studies. In general, the biowaiver studies are used for designing the change of a pharmaceutical drug after approval. Moreover, the concept of biowaiver has increased the scope of allowance of the generic drug products which is new, by the help of this irrelevant human experiments could be avoided and the price of generic drug products also could be reduced. As per USFDA, if the active pharmaceutical ingredients meet the condition of solubility and permeability at the same time and the dissolution profile of dosage form meets the criteria of immediate release; therefore, there is no need of performing the human bioequivalence study in case of biowaiver studies [43,44].

In case of advanced chemometric techniques artificial neural network (ANN) plays a very important role and also it is extensively applied in bioinformatics. Machine-learning approaches are the main principle of ANN. ANN is also can be called as a data-modeling technique. Recently ANN has been extensively applied in clinical decision making and medical classification and it is also used to solve the problems of medical prediction [45-48].
ANNs are able to achieve the convenient information from multicomponent system when the instrumental fluctuations or background noise is present; thus, ANNs are contemplated as robust models. ANNs can computerize and model the complicated relationships among inputs and outputs and also in case of two or more than two variables and it is helpful for finding patterns from data. ANN is applied for quantitative analysis of pharmaceutical preparations in multicomponent system although ANN is used for optimization purpose in chromatographic system and currently, other mathematical techniques and ANN were compared and explored for the purpose of their convenience in optimization of complicated spectrophotometric reactions. The application of ANN has been expanded for the elaboration of fluorescence biosensors which is based on nanoparticles [45].

\section{Advantage $[42,43,45]$}

It is a very easy process for the estimation of nonselective signals, and it is also done for the multiple measurement of the same sample. It is extensively used in bioinformatics. Chemometric methods can be applied in biowaiver study for correcting the interferences. For this reason, chemometric aided spectrophotometry can be contemplated as an innovation in biowaiver studies.

\section{Disadvantage [42]}

The main disadvantage of this method is the correlation of the factor, and their effect does not get separated.

\section{APPLICATION}

The various applications of UV Spectrophotometric methods are summarized in Tables 1-14.

Table 1: Application for estimation of binary mixture by simultaneous equation method in pharmaceutical dosage forms

\begin{tabular}{llll}
\hline Drug & $\begin{array}{l}\text { Spectroscopic } \\
\text { condition }\left(\boldsymbol{\lambda}_{\text {max }}\right. \\
\text { and solvent) }\end{array}$ & $\begin{array}{l}\text { Beer's } \\
\text { law range } \\
(\boldsymbol{\mu g} / \mathbf{m l})\end{array}$ & Reference \\
\hline $\begin{array}{l}\text { Rabeprazole sodium } \\
\text { and Aceclofenac }\end{array}$ & $\begin{array}{l}283 \mathrm{~nm}, 276 \mathrm{~nm} \\
\text { (methanol) }\end{array}$ & $10-60$ & {$[4]$} \\
$\begin{array}{l}\text { Levosulpiride and } \\
\text { Rabeprazole sodium }\end{array}$ & $\begin{array}{l}232 \mathrm{~nm}, 284 \mathrm{~nm} \\
\text { (methanol) }\end{array}$ & $\begin{array}{l}1-20 \text { and } \\
1-20\end{array}$ & {$[49]$} \\
$\begin{array}{l}\text { Ofloxacin and } \\
\text { Ornidazole }\end{array}$ & $\begin{array}{l}240.6 \mathrm{~nm}, 279.4 \\
\text { nm (methanol) }\end{array}$ & $\begin{array}{l}20-40 \text { and } \\
16-32\end{array}$ & {$[50]$} \\
$\begin{array}{l}\text { Norfloxacin and } \\
\text { Tinidazole }\end{array}$ & $\begin{array}{l}273 \mathrm{~nm}, 319 \mathrm{~nm} \\
\text { (methanol) }\end{array}$ & $\begin{array}{l}2.5-20 \\
\text { and 5-40 }\end{array}$ & {$[51]$} \\
Paracetamol and & $247 \mathrm{~nm}, 276 \mathrm{~nm}$, & $5-35$ and & {$[52]$} \\
Diclofenac sodium & (water) & $5-40$ & \\
\hline
\end{tabular}

Table 2: Application for estimation of ternary mixture by simultaneous equation method in pharmaceutical dosage form

\begin{tabular}{|c|c|c|c|}
\hline Drug & $\begin{array}{l}\text { Spectroscopic } \\
\text { condition }\left(\lambda_{\max } \text { and }\right. \\
\text { solvent })\end{array}$ & $\begin{array}{l}\text { Beer's } \\
\text { law range } \\
(\mu \mathrm{g} / \mathrm{ml})\end{array}$ & Reference \\
\hline $\begin{array}{l}\text { Tenofovir, Efavirenz } \\
\text { and Lamivudine }\end{array}$ & $\begin{array}{l}259 \mathrm{~nm}, 247 \mathrm{~nm}, 272 \\
\mathrm{~nm} \text { (methanol) }\end{array}$ & $\begin{array}{l}5-30 \\
10-60 \\
5-30\end{array}$ & [53] \\
\hline $\begin{array}{l}\text { Amlodipine } \\
\text { besylate, Losartan } \\
\text { potassium and } \\
\text { Hydrochlorothiazide }\end{array}$ & $\begin{array}{l}236.5 \mathrm{~nm}, 254 \mathrm{~nm}, \\
271 \mathrm{~nm} \text { (methanol) }\end{array}$ & $\begin{array}{l}5-25 \\
10-50 \\
5-25\end{array}$ & [54] \\
\hline $\begin{array}{l}\text { Amlodipine besylate, } \\
\text { Valsartan, and } \\
\text { Hydrochlorothiazide }\end{array}$ & $\begin{array}{l}359 \mathrm{~nm}, 250 \mathrm{~nm}, 317 \\
\mathrm{~nm} \text { (methanol) }\end{array}$ & $\begin{array}{l}5-25 \\
5-25 \\
10-50\end{array}$ & [55] \\
\hline $\begin{array}{l}\text { Quercetin, } \\
\text { Curcumin, and } \\
\text { Piperine }\end{array}$ & $\begin{array}{l}371.31 \mathrm{~nm}, \\
424.68 \mathrm{~nm}, 343.76 \mathrm{~nm} \\
\text { (methanol) }\end{array}$ & $\begin{array}{l}5-30 \\
1-5 \\
1-10\end{array}$ & [56] \\
\hline
\end{tabular}


Table 3: Application of $Q$ absorbance ratio method

\begin{tabular}{|c|c|c|}
\hline Drug & Wavelength & Reference \\
\hline Rabeprazole sodium & $256 \mathrm{~nm}$ (iso-absorptive point), & {$[4]$} \\
\hline and Aceclofenac & $276 \mathrm{~nm}(\lambda$ of Aceclofenac $)$ & \\
\hline Carvedilol and & $229.2 \mathrm{~nm}$ (iso-absorptive point), & {$[8]$} \\
\hline Hydrochlorothiazide & $241 \mathrm{~nm}\left(\lambda_{\max }\right.$ of Carvedilol $)$ & \\
\hline Atenolol and & $286.40 \mathrm{~nm}$ (iso-absorptive & [57] \\
\hline Ivabradine & point), $276 \mathrm{~nm}\left(\lambda_{\max }\right.$ of Atenolol) & \\
\hline Propanolol and & $272.8 \mathrm{~nm}$ (iso-absorptive point), & {$[58]$} \\
\hline Flunarizine & $253 \mathrm{~nm}\left(\lambda_{\max }\right.$ of Flunarizine $)$ & \\
\hline Prednisolon and & $283 \mathrm{~nm}$ (iso-absorptive point), & [59] \\
\hline $\begin{array}{l}\text { 5-amino salicylic acid } \\
\text { (5-ASA) }\end{array}$ & $302 \mathrm{~nm}\left(\lambda_{\max }\right.$ of $\left.5-\mathrm{ASA}\right)$ & \\
\hline Naproxen and & $234 \mathrm{~nm}$ (iso-absorptive point), & {$[60]$} \\
\hline Paracetamol & $257 \mathrm{~nm}\left(\lambda_{\max }\right.$ of Paracetamol $)$ & \\
\hline Cefixime and & $276 \mathrm{~nm}$ (iso-absorptive point), & {$[61]$} \\
\hline Moxifloxacin & $293.6 \mathrm{~nm}\left(\lambda_{\max }\right.$ of Moxifloxacin $)$ & \\
\hline Difluprednate and & $236 \mathrm{~nm}$ (iso-absorptive point), & {$[62]$} \\
\hline Gatifloxacin & $241 \mathrm{~nm}\left(\lambda_{\mathrm{max}}\right.$ of Difluprednate) & \\
\hline
\end{tabular}

Table 4: Application of difference spectroscopy for estimation of binary mixture

\begin{tabular}{|c|c|c|c|}
\hline Drug & Solvent & $\begin{array}{l}\text { Wavelength of } \\
\text { zero crossing }\end{array}$ & Reference \\
\hline $\begin{array}{l}\text { Pioglitazone } \\
\text { and } \\
\text { Metformin }\end{array}$ & $\begin{array}{l}\text { Phosphate buffer } \\
(\mathrm{pH} 9) \text { and Chloride } \\
\text { buffer (pH 2) }\end{array}$ & $\begin{array}{l}228.1 \mathrm{~nm} \text { and } \\
228.2 \mathrm{~nm}\end{array}$ & [63] \\
\hline
\end{tabular}

Table 5: Application of derivative spectrophotometry for estimation of binary mixture

\begin{tabular}{llll}
\hline Drug & $\begin{array}{l}\text { Order of } \\
\text { spectra }\end{array}$ & $\begin{array}{l}\text { Wavelength of zero } \\
\text { crossing point }\end{array}$ & Reference \\
\hline $\begin{array}{l}\text { Ofloxacin and } \\
\text { Ornidazole }\end{array}$ & 1 & $\begin{array}{l}278 \mathrm{~nm} \text { and } 293.6 \\
\mathrm{~nm}\end{array}$ & {$[50]$} \\
$\begin{array}{l}\text { Gatifloxacin and } \\
\text { Prednisolon }\end{array}$ & 1 & $348 \mathrm{~nm}$ and $263 \mathrm{~nm}$ & {$[64]$} \\
$\begin{array}{l}\text { Imipenim and } \\
\begin{array}{l}\text { Cilastatin } \\
\text { Ezetimibe and }\end{array}\end{array}$ & 1 & $243 \mathrm{~nm}$ and $300 \mathrm{~nm}$ & {$[65]$} \\
$\begin{array}{l}\text { Lovastatin } \\
\text { Minoxidil and }\end{array}$ & 1 & $265.20 \mathrm{~nm}$ and & {$[66]$} \\
Tretinoin & 1 & $245.4 \mathrm{~nm}$ & $290 \mathrm{~nm}$ and $351 \mathrm{~nm}$ \\
\hline
\end{tabular}

Table 6: Application of derivative spectrophotometry for estimation of ternary mixture

\begin{tabular}{lll}
\hline Drug & $\begin{array}{l}\text { Order of } \\
\text { spectra }\end{array}$ & $\begin{array}{l}\text { Wavelength of zero } \\
\text { crossing point }\end{array}$ \\
\hline $\begin{array}{l}\text { Amiloride } \\
\text { hydrochloride, }\end{array}$ & $1,3,1$ & $\begin{array}{l}365 \mathrm{~nm}, 265 \mathrm{~nm} \text {, and } \\
385 \mathrm{~nm}\end{array}$ \\
$\begin{array}{l}\text { Hydrochlorothiazide, } \\
\text { Timolol maleate }\end{array}$ & & \\
$\begin{array}{l}\text { Salbutamol sulfate, } \\
\text { Bromhexine and }\end{array}$ & $1,1,1$ & $\begin{array}{l}273 \mathrm{~nm}, 323 \mathrm{~nm}, \text { and [69] } \\
\text { Etofylline }\end{array}$ \\
\hline
\end{tabular}

Table 7: Application of ratio derivative spectroscopy

\begin{tabular}{lll}
\hline Drug & Wavelength & Reference \\
\hline Naphazoline and Antazoline & $227.2 \mathrm{~nm}$ and 235 nm & {$[23]$} \\
Salbutamol sulfate, Bromhexine & $247.8 \mathrm{~nm}, 248.6 \mathrm{~nm}$, & {$[69]$} \\
hydrochloride and Etofylline & $276.8 \mathrm{~nm}$ & \\
\hline
\end{tabular}

Table 8: Application of absorptivity factor method

\begin{tabular}{|c|c|c|}
\hline Drug & $\begin{array}{l}\text { Wavelength used } \\
\text { for analysis }\end{array}$ & Reference \\
\hline $\begin{array}{l}\text { Salmeterol xinafoate and } \\
\text { Fluticasone propionate }\end{array}$ & $227.8 \mathrm{~nm}$ & [32] \\
\hline $\begin{array}{l}\text { Sodium cromoglicate } \\
\text { and Fluorometholone }\end{array}$ & $241 \mathrm{~nm}$ & [70] \\
\hline
\end{tabular}

Table 9: Application of absorption factor method

\begin{tabular}{llll}
\hline Drug & $\begin{array}{l}\text { Wavelength } \\
\text { 1 (both } \\
\text { drug shows } \\
\text { absorbance) }\end{array}$ & $\begin{array}{l}\text { Wavelength } \\
\text { 2 (one } \\
\text { drug shows } \\
\text { absorbance) }\end{array}$ & Reference \\
\hline $\begin{array}{l}\text { Betamethasone valerate } \\
\text { and Tazarotene }\end{array}$ & $234 \mathrm{~nm}$ & $347 \mathrm{~nm}$ & {$[36]$} \\
$\begin{array}{l}\text { Sodium cromoglicate } \\
\text { and Fluorometholone }\end{array}$ & $241 \mathrm{~nm}$ & $325 \mathrm{~nm}$ & {$[70]$} \\
\hline
\end{tabular}

Table 10: Application of absorbance subtraction method in binary mixture

\begin{tabular}{lll}
\hline Drug & Wavelength & Reference \\
\hline Ezetimibe and Simvastatin & $248.5 \mathrm{~nm}, 256 \mathrm{~nm}$ & {$[39]$} \\
\hline
\end{tabular}

Table 11: Application of amplitude modulation method in binary mixture

\begin{tabular}{lll}
\hline Drug & Wavelength & Reference \\
\hline Ezetimibe and Simvastatin & $248.5 \mathrm{~nm}, 256 \mathrm{~nm}$ & {$[39]$} \\
\hline
\end{tabular}

Table 12: Application of ratio subtraction method and extended ratio subtraction method

\begin{tabular}{lll}
\hline Drug & Wavelength used & Reference \\
\hline $\begin{array}{l}\text { Paracetamol and } \\
\text { Orphenadrine Citrate }\end{array}$ & $248 \mathrm{~nm}$ and $220 \mathrm{~nm}$ & {$[71]$} \\
\hline
\end{tabular}

Table 13: Application of ratio difference and constant center method

\begin{tabular}{lll}
\hline Drug & Wavelength used & Reference \\
\hline Ezetimibe and & $(233.5 \mathrm{~nm}$ and $243.5 \mathrm{~nm})$, & {$[42]$} \\
Simvastatin & $(238.5 \mathrm{~nm}$ and $246.5 \mathrm{~nm})$ & \\
\hline
\end{tabular}

Table 14: Application of multivariate chemometric method for estimation of binary mixture of drugs in combined dosage form

\begin{tabular}{lll}
\hline Drug & Method used & Reference \\
\hline Minoxidil and Tretinoin & PLS & {$[72]$} \\
Levodopa and Benserazide & PLS & {$[73]$} \\
Moexipril and Hydrochlorothiazide & PLS, PCR & {$[74]$} \\
Cypermethrin and tetramethrin & PLS & {$[75]$} \\
\hline
\end{tabular}

\section{CONCLUSION}

Diverse analytical methods, including chromatography, electrophoresis, and spectrophotometry are available for the study of multicomponent samples, biological products, and matrix complexes 
but UV spectroscopic methods turns out to be an easier, simpler and rapid method for drug estimation. Thus, the present review summarizes the various aspects, advantages and disadvantages along with the applications associated with it. Simultaneous method is beneficial for its simplicity and can be used for the analysis of binary and ternary mixture of drugs. Derivative spectroscopy is more effective to analyze both the mixture and for modifying the overlapping spectra. Ratio derivative spectroscopy and successive ratio derivative spectroscopy are employed for fixing the problem of interferences, thus becoming more valuable for eliminating the chemical interferences. The difference spectroscopy method is used to analyze equimolar solutions of analyte in UV active matrix more specifically and selectively and is also applied for the analysis of binary mixture. Absorbance subtraction method and amplitude modulation method both are the new approach for the isosbestic point by the help of modern mathematical techniques without any need of complementary steps. RSM and ERSM both are applied for the estimation of multicomponent pharmaceutical formulation without having any prior separation and there is no need of derivatization. Whereas, constant center method is more accurate than the second derivative method for the measurement of the drug concentration in zero-order. Chemometric methods are done for the multiple measurement of the same sample and also it is extensively used in biowaiver study for correcting the interferences. Thus, looking into the prospects of UV spectroscopic methods it might absolutely be used for estimation of drugs, having less troubleshooting problems and physicochemical interferences in contrast to other sophisticated analytical instruments.

\section{ACKNOWLEDGMENT}

NA.

\section{AUTHORS' CONTRIBUTION}

All the authors have made equal contribution.

\section{CONFLICTS OF INTEREST}

None declared.

\section{AUTHOR'S FUNDING}

NA.

\section{REFERENCES}

1. Sharma YR. Elementary Organic Spectroscopy Principles and Chemical Application. $5^{\text {th }}$ ed. New Delhi: S. Chand Publishing; 2013.

2. Sankar SR. Textbook of Pharmaceutical Analysis. $5^{\text {th }}$ ed. Tirunelveli, India: RX Publications; 2018.

3. Pavia D, Lampman G, Kriz G. Introduction to Spectroscopy. $4^{\text {th }}$ ed. Bloomington, IN: Indiana University; 2001.

4. Sawant RL, Hadawale SD, Dhikale GK, Bansode CA, Tajane PS. Spectrophotometric methods for simultaneous estimation of rabeprazole sodium and aceclofenac from the combined capsule dosage form. Pharm Methods 2011;2:193-7.

5. Beckett AH, Stenlake JB. Pharmaceutical Chemistry. $4^{\text {th }}$ ed. New Delhi: CBS Publishers; 2000.

6. Giriraj P, Sivakkumar T. New simple spectrophotometric method for the simultaneous estimation of paracetamol and flupirtine maleate in pure and pharmaceutical dosage form. Int J Spectrosc 2014;2014:968420.

7. Atole MD, Rajput HH. Ultraviolet spectroscopy and pharmaceutical applications: A brief review. Asian J Pharm Clin Res 2018;11:59-66.

8. Abdelwahab SN. Spectrophotometric methods for simultaneous determination of carvedilol and hydrochlorothiazide in combined dosage form. Arab J Chem 2016;9:S355-60.

9. Prabhu SL, Shanmugarathinam A. Development of difference spectrophotometric method for the estimation of leflunomide in tablet dosage form. Chem Ind Chem Eng Quart 2012;18:407-10.

10. Nikolaidis A, Moschakis T. Studying the denaturation of bovine serum albumin by a novel approach of difference-UV analysis. Food Chem 2016;215:235-44.

11. Affleck RP, Spitznagel TM. Application of difference spectroscopy to biopharmaceutical formulation development. Am Lab 2017;1:6-9.

12. Owen JA. Uses of Derivative Spectroscopy. United States: Agilent Technologies; 2020 .

13. Karpinska J. Basic principles and analytical application of derivative spectrophotometry. In: Macro to Nano Spectroscopy. Poland, Bialystok: IntechOpen; 2012. p. 254-68.

14. Savitzky A, Golay MJ. Smoothing and differentiation of data by simplified least squares procedures. Anal Chem 1964;36:1627-42.

15. Ojeda CB, Rojas FS. Recent application in derivative ultraviolet/visible absorption spectrophotometry: 2009-2011. A review. Microchem J 2013;106:1-16.

16. Ojeda CB, Rojas FS. Recent development in derivative ultraviolet/ visible absorption spectrophotometry: 2004-2008. A review. Anal Chem Acta 2009;635:22-44.

17. Korany MA, Haggag RS, Ragab MA, Elmallah OA. Kinetic investigation of pentoxifylline based on non-parametric linear regression of derivative and convulated derivative chromatographic and spectrophotometric responses. J Liquid Chromatogr Relat Technol 2013;37:475-97.

18. Korany MA, Elsayed MA, Bedair MM, Mahgoub H, Korany EA. Computer-assisted spectrometry: Multicomponent analysis with a discrete Fourier transform. Talanta 1990;37:1183-8

19. Korany MA, Fahmy OT, Mahgoub H, Maher HM. Non-parametric linear regression of discrete Fourier transform convoluted chromatographic peak responses in non-ideal conditions. Talanta 2005;66:1073-87.

20. Korany MA, Maher HM, Galal SM, Fahmy OT, Ragab MA. Nonparametric linear regression of discrete Fourier transform convoluted chromatographic peak responses under non-ideal conditions of internal standard method. Talanta 2010;83:93-109.

21. Korany MA, Abdine HH, Ragab MA, Aboras SI. Application of derivative spectrophotometry under orthogonal polynomial at unequal intervals: Determination of metronidazole and nyastatin in their pharmaceutical mixture. Spectrochem Acta Part A Mol Biomol Spectrosc 2015;143:281-7.

22. Grandage A, George W. Orthogonal coefficients for unequal intervals. Biometrics 1958;14:287-9.

23. El-Yazbi FA, Hammud HH, Assi SA. Derivative-ratio spectrophotometric method for the determination of ternary mixture of aspirin, paracetamol and salicylic acid. Spectrochim Acta Part A Mol Biomol Spectrosc 2007;68:275-8.

24. Mahgoub HH, El-Yazbi FA, Barary MH. Derivative and derivativedifference spectrophotometric determination of captopril in twocomponent mixture. Sci Pharm 1992;60:239-45.

25. El-Yazbi FA, Korany MA, Abdine HH, El-Sayed MA. Derivative spectrophotometric determination of some tranquilizer antidepressant mixtures. Spectrosc Lett 1991;24:437-49.

26. El-Yazbi FA. Second-derivative spectrophotometric determination of famotidine. Spectrosc Lett 1992;25:1011-2.

27. Nevado JJ, Cabanillas GG, Salinas F. Spectrophotometric resolution of ternary mixtures of salicylaldehyde, 3-hydroxybenzaldehyde by the derivative ratio spectrum-zero crossing method. Talanta 1992;39:547-53.

28. El-Yazbi FA, Abdine HH, Shalaan RA. Spectrophotometric method for the determination of benazepril hydrochloride in its single and multicomponent dosage forms. J Pharm Biomed Anal 1999;20:343-50.

29. El-Yazbi FA, Kovar KA. A computerised spectrophotometric method for the determination of atenolol and nifedipine in presence of degradation products of nifedipine. Sci Pharm 1998;66:325-33.

30. Hajian R, Shams N, Kaedi I. Application of ratio derivative spectrophotometry for simultaneous determination of naphazoline and antazoline in eye drops. E J Chem 2010;7:1530-8.

31. Afkami A, Bahram M. Successive ratio-derivative spectra as a new spectrophotometric method for the analysis of ternary mixtures. Spectrochim Acta Part A Mol Biomol Spectrosc 2005;61:869-77.

32. Samir A, Salem H, Abdelkawy M. New developed spectrophotometric method for simultaneous determination of salmeterol xinafoate and fluticasone propionate in bulk powder and seritide diskus inhalation. Bull Fac Pharm Cairo Univ 2012;50:121-6.

33. Abdelkawy SM, Amer M, Lotfy HM, Zaazaa H. Simple spectrophotometric analysis of benzapril hydrochloride or valsartan in combined pharmaceutical dosages with hydrochlorothiazide. Bull Fac Pharm Cairo Univ 2004;44:25-32.

34. El-Ghobashya MR, Abo-Talibb NF. Spectrophotometric methods for the simultaneous determination of metronidazole and diloxanide furoate without prior separation. J Adv Res 2010;1:323-9.

35. Pandurang ND, Sunita RB. Simultaneous UV spectrophotometric methods for estimation of amlodipine besylate and olmesartan medoxomil in tablet dosage form. J Chem Pharm Res 2011;3:650-6. 
36. Mahmood A, Rapalli VK, Waghule T, Gorantla S, Dubey SK, Saha RN, et al. UV spectrophotometric method for simultaneous estimation of betamethasone valerate and tazarotene with absorption factor method: Application for in-vitro and ex-vivo characterization of lipidic nanocarriers for topical delivery. Spectrochim Acta Part A Mol Biomol Spectrosc 2020;235:1-8.

37. Kamal AH, El-malla SF, Hammad SF. A review on UV spectrophotometric methods for simultaneous multicomponent analysis. Eur J Pharm Med Res 2016;3:348-60.

38. Lotfy HM, Hegazy MA. Simultaneous determination of some cholesterol lowering drugs in their binary mixture by novel spectrophotometric methods. Spectrochim Acta Part A Mol Biomol Spectrosc 2013;113:107-14.

39. Lotfy HM. Absorbance subtraction and amplitude modulation as novel spectrophotometric methods for the analysis of binary mixtures. Int $\mathbf{J}$ Pharm Pharm Sci 2014;6:735-41.

40. Lotfy HM, Hagazy M. Comparative study on novel spectrophotometric methods manipulating ratio spectra: An application on pharmaceutical ternary mixture of omeprazole, tinidazole and clarithromycin. Spectrochim Acta Part A Mol Biomol Spectrosc 2012;96:259-70.

41. Lotfy HM. Determination of simvastatin and ezetimibe in combined tablet dosage forms by constant centre spectrophotometric method. Int J Pharm Pharm Sci 2012;4:673-9.

42. Hassaninejad-Darzi SK, Samadi-Maybodi A, Mohsen S. UV-vis spectrophotometry and multivariate calibration method for simultaneous determination of theophylline, montelukast and loratadine in tablet preparations and spiked human plasma. Iran J Pharm Res 2016;15:379-91.

43. Korany MA, Mahgoub H, Haggag RS, Ragab MA, Elmallah OA. Chemometrics-assisted spectrophotometric green method for correcting interferences in biowaiver studies: Application to assay and dissolution profiling study of donepezil hydrochloride tablets. Spectrochim Acta Part A Mol Biomol Spectrosc 2018;199:328-39.

44. Guidance for Industry. Waiver of In Vivo Bioavailability and Bioequivalence Studies for Immediate-Release Solid Oral Dosage Forms Based on a Biopharmaceutics Classification System. United Kingdom: Guidance for Industry; 2000.

45. Korany MA, Gazy AA, Khamis EF, Ragab MA, Kamal MF. Analysis of closely related antioxidant nutraceuticals using the green analytical methodology of ANN and smart spectrophotometric methods. J AOAC Int 2017;100:8-17

46. Miller JN, Miller JC. Statistics and Chemometrics for Analytical Chemistry. $5^{\text {th }}$ ed. Harlow, United Kingdom: Prentice Hall; 2000.

47. Crooke PS, Tossberg JT, Horst SN, Tausher ZL, Henderson MA, Beaulieu DB, et al. Using gene expression data to identify certain gastro-intestinal diseases. J Clin Bioinform 2012;2:1-11.

48. Westreich D, Lessler J, Funk MJ. Propensity score estimation: Neural networks, support vector machines, decision trees (CART), and metaclassifiers as alternatives to logistic regression. J Clin Epidemiol 2010;63:826-33.

49. Shetty PR, Patil DD. Application of simultaneous equation method and derivative for the determination of rabeprazole sodium and levosulpiride in pharmaceutical dosage form and dissolution samples. J Assoc Arab Univ Basic Appl Sci 2014;15:53-60.

50. Patel PB. Development and validation of a method for simultaneous estimation of ofloxacin and ornidazole in different dissolution media. Pharm Methods 2012;3:102-5.

51. Pant M, Dadare K, Khatri NC. Application UV spectrophotometric methods for simultaneous estimation of norfloxacin and tinidazole in bulk and tablet dosage forms. Der Pharma Chem 2012;4:1041-6.

52. Sharma R, Pathodiya G, Mishra GP, Sainy J. Spectrophotometric methods for simultaneous estimation of paracetamol and diclofenac sodium in combined dosage form by application of hydrotropic solubilization. J Pharm Sci Res 2010;2:821-6.

53. Sharma R, Mehta K. Simultaneous spectrophotometric estimation tenofovir disoproxil fumarate and lamivudine in three component tablet formulation containing efavirenz. Indian J Pharm Sci 2010;72:527-30.

54. Wankhede SB, Raka KC, Wadkar SB, Chitlange SS. Spectrophotometric and HPLC methods for simultaneous estimation of amlodipine besylate, losartan potassium and hydrochlorothiazide in tablets. Indian J Pharm Sci 2010;72:136-40.

55. Galande V, Baheti K, Indraksha S, Dehgan M. Estimation of amlodipine besylate, valsartan and hydrochlorthiazide in bulk mixture and tablet by
UV spectrophotometry. Indian J Pharm Sci 2012;74:18-23.

56. Aneja G, Dave U, Vadodaria K. Simultaneous estimation of piperine, quercetin and curcumin in a mixture using UV-visible spectrophotometer and method validation. Int J Ther Appl 2012;8:14-7.

57. Patil PA, Raj HA, Sonara GB. Q-absorbance ratio spectrophotometric method for simultaneous determination of atenolol and ivabradine hydrochloride in synthetic mixture. Pharm Biol Evol 2016;3:224-30.

58. Patil A, Surana S. Q-absorbance and multicomponent UV spectrophotometric methods for simultaneous estimation of propranolol. Scholars research library. Der Pharma Chem 2016;3:404-8.

59. Singh G, Kumar D, Sharma D, Singh M. Q-absorbance ratio spectrophotometric method for the simultaneous estimation of prednisolone and 5-amino salicylic acid in tablet dosage form. J Appl Pharm Sci 2012;2:222-6.

60. Patil A, Firke SD, Bari SB, Ranoliya JR. Development and validation of UV spectrophotometric method for simultaneous estimation of naproxen and paracetamol by Q-absorbance ratio method. Int J Pharm Res Allied Sci 2014;3:57-63.

61. Attimarad M, Aldhubiab BE, Alhaider IA, Nair AB. Simultaneous determination of moxifloxacin and cefixime by first and ratio first derivative ultraviolet spectrophotometry. Chem Central J 2012;6:105.

62. Patel P, Patel D, Desai S, Meshram D. Development and validation of analytical methods for simultaneous estimation of difluprednate and gatifloxacin in ophthalmic emulsion by UV visible spectroscopy. Int J Pharm Sci Invent 2014;3:1-10.

63. Sujana K, Abbulu K, Souri OB, Archana B, Sindu M, Rani GS, et al. Difference spectrophotometric methods for pioglitazone hydrochloride and metformin hydrochloride. J Pharm Sci Res 2011;3:1122-6.

64. Rosa AM, Sversut A, Alca IC. Simultaneous determination of gatifloxacin and prednisolone acetate in ophthalmic formulation using first order UV derivative spectroscopy. Arab J Chem 2014;10:604-10.

65. Tabbouche OS, Soukkariyyeh I. First order derivative ultraviolet spectrophotometry of imipenem E cilastatin formulations. J Taibah Univ Med Sci 2014;9:178-81.

66. Rajput S, Raj H. Simultaneous estimation of ezetimibe and lovastatin by derivative spectroscopy. Int J Pharm Tech Res 2009;1:894-9.

67. Mahrous MS, Abdel-Khalek MM, Beltagy YA. Simultaneous quantitation of minoxidil and tretinoin in magistral and pharmaceutical preparations by first derivative spectrophotometry. Anal Lett 1992;25:1673-86.

68. Abdel-hay MH, Gazy AA, Hassan EM, Belal TS. Derivative and derivative ratio spectrophotometric analysis of antihypertensive ternary mixture of amiloride hydrochloride, hydrochlorthiazide and timolol maleate. J Chine Chem Soc 2008;55:971-8.

69. Dave HN, Mashru RC, Thakkar AR. Simultaneous determination of salbutamol sulphate, bromhexine hydrochloride and etofylline in pharmaceutical formulations with the use of four rapid derivative spectrophotometric methods. Anal Chim Acta 2007;597:113-20.

70. Saleh SS, Lotfy HM, Hassan NY, Elgizawy SM. A comparative study of validated spectrophotometric and TLC-spectro densitometric methods for the determination of sodium cromoglicate and fluorometholone in ophthalmic solution. Saudi Pharm J 2013;21:411-21.

71. Sebaity MM, Mattar AA. Ratio subtraction coupled with extended ratio subtraction method for simultaneous determination of paracetamol and orphenadrine citrate in their combined pharmaceutical dosage forms. Int J Modern Pharm Res 2020;4:1-5.

72. Bordbar M, Yeganeh-Faal A, Ghasemi J, Ahari-Mostafavi MM, Sarlak N, Baharifard MT. Simultaneous spectrophotometric determination of minoxidil and tretinoin by the H-point standard addition method and partial least squares. Chem Papers 2009;63:336-44.

73. Coello J, Maspoch S. Simultaneous kinetic spectrophotometric determination of levodopa and benserazide by bi-and three-way partial least squares calibration. Talanta 2000;53:627-37.

74. Tawakkol S, Farouk M, Delaziz M, Hemdan A, Shehata M. Comparative study between univariate spectrophotometry and multivariate calibration as analytical tools for simultaneous quantitation of moexipril and hydrochlorthiazide. Spectrochim Acta Part A Mol Biomol Spectrosc 2014; 133:300-6.

75. Niazi A, Goodarzi M. Orthogonal signal correction-partial least squares method for simultaneous spectrophotometric determination of cypermethrin and tetramethrin. Spectrochim Acta Part A Mol Biomol Spectrosc 2008;69:1165-9. 